\title{
RAPID DETECTION OF Salmonella IN SHRIMP BY POLYMERASE CHAIN REACTION
}

\author{
[Deteksi Cepat Salmonella pada Udang dengan Polymerase Chain Reaction]
}

\author{
Ulfah Amalia ${ }^{1,2)}$, Ratih Dewanti-Hariyadi2,3|* and Achmad Poernomo4) \\ 1) Faculty of Fisheries and Marine Science, Diponegoro University, Semarang \\ 2) Department of Food Science and Technology, Bogor Agricultural University, Bogor \\ 3) Southeast Asian Food and Agricultural Science and Technology (SEAFAST) Center, Bogor Agricultural University, Bogor \\ 4) Center for Research and Development and Product Processing and Marine Biotechnology Fisheries (CRDPPMBF), the Ministry of \\ Marine Affairs and Fisheries, Jakarta
}

Accepted September $27^{\text {th }} 2013$ / Approved July $4^{\text {th }} 2014$

\begin{abstract}
Shrimp is an important non-oil commodity for foreign trade in Indonesia. However, rejection of shrimp exports by the importing countries is still commonly encountered. In 2011, the USFDA recorded two cases of Salmonella spp. contamination in shrimp products from two shrimp processing companies in Indonesia. Analysis of Salmonella spp. in seafood is generally performed using a conventional method which takes at least 5 days. The objective of the study is to get a Salmonellae rapid detection method in shrimp by PCR. In this study, optimization of PCR protocol method to detect Salmonella invA gene was conducted using six different annealing temperatures $\left(59,59.5,60.8,62,64\right.$ and $\left.64.5^{\circ} \mathrm{C}\right)$. The results showed that $64^{\circ} \mathrm{C}$ was the optimum annealing temperature to detect the $284 \mathrm{bp}$ fragment of Salmonella invA gene. The PCR based detection method has a DNA detection limit of $27.81 \mu \mathrm{g} / \mathrm{mL}$ and $10^{\circ} \mathrm{CFU} / \mathrm{mL}$ of viable salmonellae with $100 \%$ specificity. The PCR protocol is capable of detecting six different Salmonella serovars (S. Enteritidis, S. Hadar, S. Heidelberg, S. Kentucky, S. Paratyphi and S. Typhimurium) but none of the non salmonellae isolates. Application of the PCR assay on Salmonella in shrimp after the selective enrichment step suggested that all 16 samples were positive for Salmonella. At the same time, the conventional method could only detected 3 samples for Salmonella positive.
\end{abstract}

Keywords: invA gene, optimization, PCR, Salmonella spp., shrimp

\begin{abstract}
ABSTRAK
Udang merupakan sumber non migas yang penting dalam perdagangan internasional di Indonesia. Namun, kasus penolakan ekspor udang oleh negara pengimpor masih sering ditemui. Pada tahun 2011, USFDA mencatat dua kasus kontaminasi Salmonella spp. pada produk udang dari dua industri pengolahan udang di Indonesia. Pengujian Salmonella spp. pada seafood umumnya menggunakan metode konvensional yang membutuhkan waktu minimal 5 hari. Penelitian ini bertujuan untuk mendapatkan metode deteksi cepat Salmonellae dalam udang dengan metode PCR menggunakan sekuens gen invA. Pada penelitian ini, dilakukan optimasi protokol PCR untuk mendeteksi Salmonella spp. dengan 6 suhu annealing yang berbeda $\left(59 ; 59.5 ; 60.8 ; 62 ; 64\right.$ dan $\left.64.5^{\circ} \mathrm{C}\right)$. Hasil penelitian menunjukkan bahwa suhu annealing $64^{\circ} \mathrm{C}$ optimum untuk mendeteksi fragmen gen invA Salmonella spp. pada 284 bp. Protokol PCR ini memiliki limit deteksi terhadap DNA sebesar $27.81 \mu \mathrm{g} / \mathrm{mL}$ dan kultur Salmonella spp. sebesar $10^{\circ} \mathrm{CFU} / \mathrm{mL}$ dengan spesifisitas $100 \%$. Metode PCR tersebut mampu mendeteksi 6 serovar Salmonella yang berbeda (S. Enteritidis, S. Hadar, S. Heidelberg, S. Kentucky, S. Paratyphi dan S. Typhimurium), dan tidak mengenali non Salmonella. Aplikasi protokol PCR terpilih pada Salmonella spp. dalam udang segar setelah tahap pengayaan selektif menunjukkan bahwa ke-16 sampel positif mengandung Salmonella spp. Metode konvensional hanya mampu mendeteksi 3 sampel sebagai positif mengandung Salmonella spp.
\end{abstract}

Kata kunci: gen invA, optimasi, PCR, Salmonella spp., udang

\section{INTRODUCTION}

For Indonesia, shrimp is an important food commodity for export (Ministry of Marine Affairs and Fisheries, 2012). However, export and rejection is still frequently encountered due to Salmonellae, Vibrio parahaemolyticus (Ministry of Marine Affairs and Fisheries, 2010) as well as chemical residues (Ministry of Marine Affairs and Fisheries, 2012). Between

*Corresponding Author:

Email: rdewanti@uwalumni.com

Tel +62 251-8620069/8626725, Fax :+62 2518626725
January-December 2010, the import rejection of fisheries products from Indonesia due to Salmonella spp. was $65 \%$. Presence of Salmonella spp. in fish and fisheries products from Indonesia have been reported. Dewanti-Hariyadi et al. (2005) reported that 2 of 32 ocean shrimp samples contaminated with Salmonella spp., whereas in aquaculture shrimp samples 4 of 32 samples were contaminated by Salmonella spp. Salmonella spp. was found in aquaculture shrimp located Tangerang (2.4\%) and Karawang (24-29\%), West Java (Rusyanto, 2005). Contamination of Salmonella was also found in frozen cooked shrimp (Norhana et al. 2010). 
Salmonella spp. can contaminate shrimp from the aquatic environments during harvest and handling. Absence of Salmonella spp. in shrimp is generally tested using conventional methods which take more than 5 days. With advances in technology, a variety of detection methods have been developed. Detection method of Salmonella spp. based on PCR has been reported by Hyeon et al. (2010) and Upadhyay et al. (2010).

Devananda (2011) reported that testing Salmonella spp. using conventional method is effective and has been used to isolate and identify Salmonella spp. in food, but the procedure is very complex and resources consuming. Polymerase Chain Reaction (PCR) based method is more sensitive, specific and faster than conventional method. It also improves the limit of quantitative detection for Salmonella (Ellingson et al. 2004).

Various detection limits and accuracies have been observed with the use of different primers to detect Salmonella (Malorny et al. 2003). Several primers were reported to amplify and detect Salmonella spp. with the following gene targets: replication oriC Salmonella spp. (Devananda, 2011), invA and E (virulence genes) (Trafny et al. 2006; Shanmugasamy et al. 2011; Zou et al. 2011). The objective of this study was to develop a PCR based method to detect Salmonella spp. in shrimp employing an invA gene primer. The use of these genes as a potential target for Salmonella identification has been suggested since these genes were shown to be present in a number of Salmonella strains. Primers amplify and detect a fragment of invA, a highly conserved gene present in almost all salmonella serotypes (Upadhyay et al. 2010; Devananda, 2011).

\section{MATERIALS AND METHODS}

\section{Bacterial isolates}

Bacteria used for this study were 6 different Salmonella serovars, i.e. S. Enteritidis, S. Hadar, S. Heidelberg, S. Kentucky, S. Paratyphi obtained from SEAFAST CENTER (Dewanti-Hariyadi et al. 2005) and S. Typhimurium obtained from Microbiology Lab, CRDPPMBF, Jakarta, Indonesia. Five non-Salmonellae which frequently contaminate food were used as negative controls, i.e. E. coli, L. monocytogenes, P. mirabilis, $S$. aureus, $V$. parahaemolyticus. These bacteria were provided by Microbiology Lab, CRDPPMBF, Jakarta, Indonesia.

\section{DNA extraction for PCR (invitrogen ${ }^{\mathrm{TM}}$ )}

Purification of genomic DNA was conducted using The PureLink ${ }^{\mathrm{TM}}$ Genomic DNA Mini Kits (invitrogen ${ }^{\mathrm{TM}}$ ) by a spin column based centrifugation procedure. DNA was extracted from $1 \mathrm{~mL}$ aliquots of overnight bacterial culture in Tryptone Soya Broth (TSB) (Oxoid, England). In brief, one $\mathrm{mL}$ aliquots of bacterial culture was centrifuged at $4.000 \mathrm{~g}$ for 10 minutes and the cell pellets were suspended in $190 \mu \mathrm{L}$ TE Buffer (invitrogen ${ }^{\mathrm{TM}}$ ) and $10 \mu \mathrm{L}$ Lysozyme (invitrogen ${ }^{\mathrm{TM}}$ ) (for Gram negative) or $100 \mu \mathrm{L}$ TE Buffer dan $100 \mu \mathrm{L}$ Lysozyme (for Gram positive) and incubated at $30^{\circ} \mathrm{C}$ for 30 minutes. The cell suspensions were centrifuged at $4.000 \mathrm{~g}$ for 5 minutes and the cell pellets were resuspended in $400 \mu \mathrm{L}$ of DNA Lysis Buffer $T$ (invitrogen ${ }^{\mathrm{TM}}$ ), added with $20 \mu \mathrm{L}$ Proteinase $\mathrm{K}$ (invitrogen ${ }^{\mathrm{TM}}$ ), 15 $\mu \mathrm{L}$ RNaseA (invitrogen ${ }^{\top M}$ ) and mixed well by brief vortexing. The mixture was incubated at $70^{\circ} \mathrm{C}$ for 30 minutes and $200 \mu \mathrm{L}$ of DNA Binding Buffer (invitrogen ${ }^{\mathrm{T} M}$ ) was added. Purification was conducted by adding the mixture into spin column and centrifugation at $10.000 \mathrm{~g}$ for 1 minutes. The spin column containing solid phase was moved to new tubes, added with $650 \mu \mathrm{L}$ DNA Wash Buffer (invitrogen ${ }^{\mathrm{TM}}$ ) containing 100\% ethanol, and centrifuged at $10.000 \mathrm{~g}$ for 10 minutes. The spin column was placed in a new sterile $1.5 \mathrm{~mL}$ microcentrifuge tube and added with $50 \mu \mathrm{L}$ DNA Elution Buffer (invitrogen ${ }^{\mathrm{TM}}$ ), incubated at room temperature for 3 minutes. DNA precipitation was carried out by centrifugation at $6.000 \mathrm{~g}$ for 1 minute. To recover more DNA, a second elution step was performed using the same volume of the same elution buffer. The clear supernatant (DNA) was collected and stored at $-20^{\circ} \mathrm{C}$ for PCR. The concentration of DNA was determined by optical density (OD) at the wavelength of $260 \mathrm{~nm}$ (Bio-Spectrometer, Eppendorf) and its purity was evaluated by the ratio of $\mathrm{OD}$ at the wavelength of $260 / 280$. The DNA were kept at $-20^{\circ} \mathrm{C}$ until further use.

\section{Optimization of PCR method to detect Salmonella invA gene (modified Rahn et al. 1992)}

The specific primers for invA gene amplification consisted of a forward primer F139 and a reverse primer R141 with sequences 5'GTGAAATTATCGCCACGTTCGGGCAA-3' and 5'TCATCGCACC GTCAAAGGAACC-3', respectively (Rahn et al. 1992). These primers amplify gene encoding for invA located within 287 to 312 and 571 to 550 bp regions (AlT-Biotech Singapore). PCR amplification was performed with PCR Applied Biosystem 2720 Cycler (Foster City, California) using PCR mixtures containing $1.5 \mu \mathrm{L}$ of primers, $7.5 \mu \mathrm{L}$ PCR Master Mix (0.05 U/ $\mu \mathrm{L}$ Taq DNA polymerase, PCR buffer, $\mathrm{MgCl}_{2}$ and dNTP) (Thermo Scientific). The thermocycling conditions were $95^{\circ} \mathrm{C}$ for 1 minute, followed by 35 cycles of denaturation at $95^{\circ} \mathrm{C}$ for 30 seconds, annealing at $59 ; 59.5 ; 60.8 ; 62 ; 64$; or $64.5^{\circ} \mathrm{C}$ for 30 seconds and elongation at $72^{\circ} \mathrm{C}$ for 30 seconds, with a final extension at $72^{\circ} \mathrm{C}$ for 4 minutes. The PCR products were visualized by electrophoresis on $1.5 \%$ agarose gel (Fermentas, USA) at $100 \mathrm{~V}$ for 30 minutes, stained with SYBR SAFE $\left(0.6 \mu \mathrm{g} / 100 \mathrm{~mL}\right.$ ) (invitrogen ${ }^{\mathrm{TM}}$ ), visualized under UV transilluminator (Bio-Rad) and photographed. DNA from reference strain $S$. Typhimurium and $S$. aureus was used as positive and negative control, respectively.

\section{Sensitivity and specificity of PCR (Upadhyay et al. 2010)}

The sensitivity of PCR assay was evaluated in various concentration of DNA and various concentration of viable $S$. Typhimurium. For sensitivity test based on DNA concentration, DNA extract was sequentially diluted ten folds. For sensitivity test based on viable bacterial count, $S$. Typhimurium was sequentially diluted from $10^{9}$ to $1 \mathrm{CFU} / \mathrm{mL}$ and DNA was extracted from each dilution. DNA extracted from $S$. Typhimurium and $S$. aureus was used as positive and negative control, respectively in each PCR run. The PCR products were visualized by electrophoresis and observed as described above. The minimum concentration of DNA giving a positive signal was recorded. The specificity of PCR was evaluated by comparing 
with 6 different Salmonella serovars (S. Enteritidis, S. Hadar, S. Heidelberg, S. Kentucky, S. Paratyphi and S. Typhimurium) and cross-tested with 5 non-Salmonella isolates, i.e. of $E$. coli, $L$. monocytogenes, $P$. mirabilis, S. aureus, V. parahaemolyticus.

\section{Application of the PCR assay on Salmonella isolated from shrimp in fresh markets}

The PCR method developed was applied to detect Salmonella from shrimp samples. Briefly, 16 shrimp samples were collected from 5 fresh markets in Jakarta. Samples were pre-enriched in $225 \mathrm{~mL}$ of Buffered Peptone Water (BPW) (Oxoid, England) and incubated at $37^{\circ} \mathrm{C}$ for 24 hour, and then selectively enriched in Muller Kauffmann Tetrathionate Broth (MKTTn) (Oxoid, England) for 24 hours at $37^{\circ} \mathrm{C}$. A conventional method was carried out according to ISO 6579:2002. Using this method, selective enrichment was conducted in RappaportVassiliadis Broth (RV) (Oxoid, England) and MKTTn and incubated for 24 hours at $42^{\circ} \mathrm{C}$ and $37^{\circ} \mathrm{C}$, respectively, followed by selective isolation onto Xylose Lysine Deoxycholate Agar (XLDA) (Oxoid, England) and Brilliance Salmonella Agar (BSA) (Oxoid, England) plates and incubated for 24 hours at $37^{\circ} \mathrm{C}$. Typical colonies were streaked onto Triple Sugar Iron Agar (TSIA) (Oxoid, England) and Lysine Iron Agar (LIA) (Oxoid, England), and incubated for 24 hours at $37^{\circ} \mathrm{C}$. Single colony was confirmed with Microgen GN A-ID System (Microgen Bioproducts). Growth in MKTTn was centrifuged at $20.000 \mathrm{~g}$ for 5 minutes and the DNA was extracted for the cell pellets as above for PCR assay.

\section{RESULTS AND DISCUSSION}

\section{Annealing temperature maximum}

Isolation of DNA from bacteria is the initial step in determining the genotypic characteristics of bacteria. In this study, the chromosomal DNA was extracted by spin-column technology. The bacterial cell wall was removed by lysozyme and proteinase $\mathrm{K}$. Addition of ethanol was applied to wash the DNA or oligonucleotide-DNA extraction from small oligonucleotides, while detergent and organic solvent were used to remove proteins. The genomic DNA concentration of $S$. Typhimurium extracted by this method was $2.486 \mu \mathrm{g} / \mathrm{mL}$. According to Wilkerson et al. (1993), the concentration of DNA for PCR ranged from 0.5 to $6.5 \mu \mathrm{g} / \mathrm{mL}$. The purity of DNA extracted obtained in this study was 1.88 which was complied with the standard value of 1.8 to 2.0 (Sambrook et al. 2001).

Amplified primer of gene encoding for invA of $S$. Typhimurium at different annealing temperatures $59^{\circ} \mathrm{C}$ up to $64.5^{\circ} \mathrm{C}$ resulted clear and thick band of $284 \mathrm{bp}$. The results indicate that annealing temperatures used in this study were suitable for the amplification of the Salmonella invA gene. One way to optimize detection method by PCR is directed at the factors that affect annealing or extension (Devananda, 2011). Yuwono (2006) states that annealing temperatures at 55 to $65^{\circ} \mathrm{C}$ increase the specificity of the amplification reaction, although decrease the overall efficiency. In this study, annealing temperature of $64^{\circ} \mathrm{C}$ provides the thickest band, accordingly selected for further use (Figure 1).

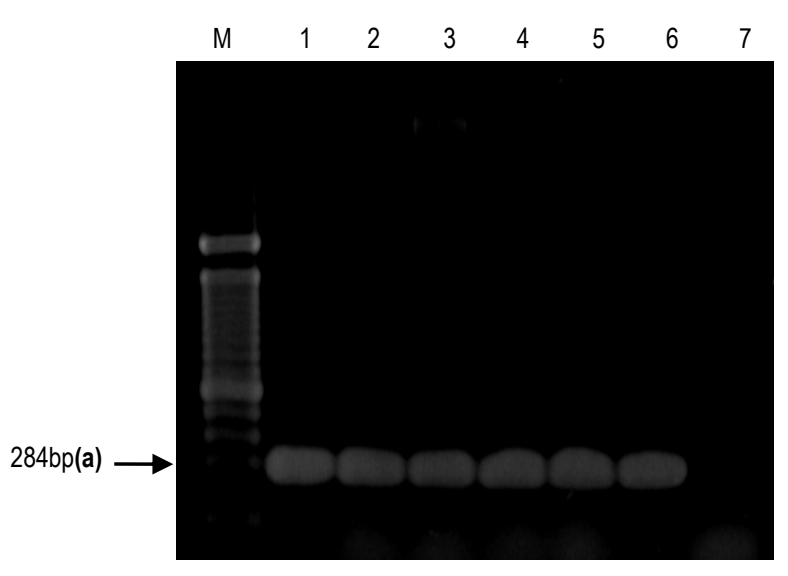

Figure 1. Visualization of DNA amplification products invA gene $S$. Typhimurium at different annealing temperatures, lanes 1-6: $59 ; 59.5 ; 60.8 ; 62 ; 64 ; 64.5^{\circ} \mathrm{C}$ respectively, lane $7: \mathrm{S}$. aureus as a negative control, lane $\mathrm{M}$ is a marker $100 \mathrm{bp}$ DNA ladder

\section{Sensitivity and specificity PCR methods}

The specific bands of invA gene at 284 bp can be detected at DNA dilution up to $10^{-5}$ (Figure 2 (a)), i.e. a DNA concentration of $27.81 \mu \mathrm{g} / \mathrm{mL}$ as measured by Bio-Spectrometer. The sensitivity was evaluated in various concentration of viable cell showed that invA gene can be detected at the highest dilution concentration (1 CFU/mL) (Figure 2 (b)). The negative control, $S$. aureus did not give any amplicons. The results showed better sensitivity than Upadhyay et al. (2010) who reported a sensitivity of $10^{4} \mathrm{CFU} / \mathrm{mL}$.

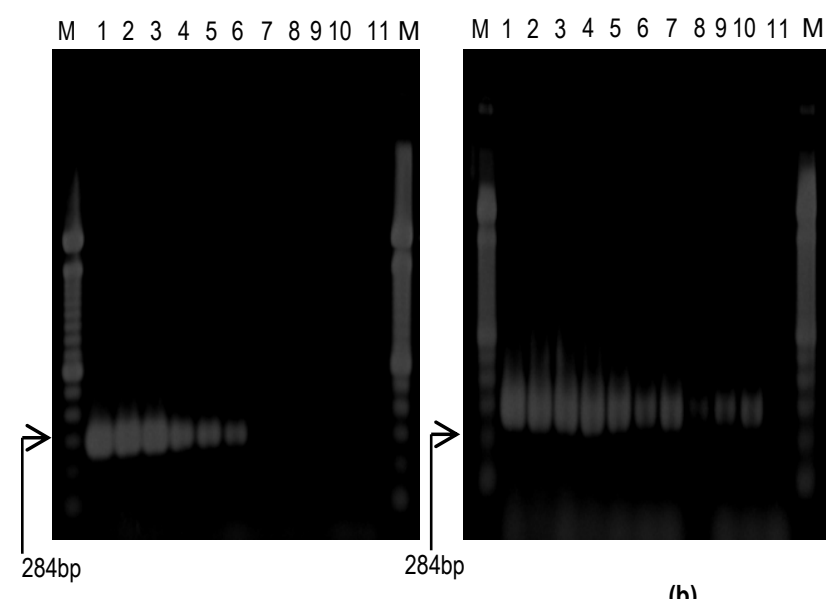

(a)

(b)

Figure 2. invA gene Salmonella amplification products on a $1.5 \%$ agarose gel (TBE). Detection limit of PCR (a). Lanes 1-10: Dilution of $S$. Typhimurium DNA extracted from $10^{0}-10^{-9}$; lane 11: S.aureus DNA as a negative control; lane M: DNA marker 100 bp ladder. (b). Lanes 1-10: Dilution of $S$. Typhimurium culturesfrom 109-1 CFU/mL; lane 11: $S$. aureus DNA as a negative control; lane M: DNA marker $100 \mathrm{bp}$ ladder 

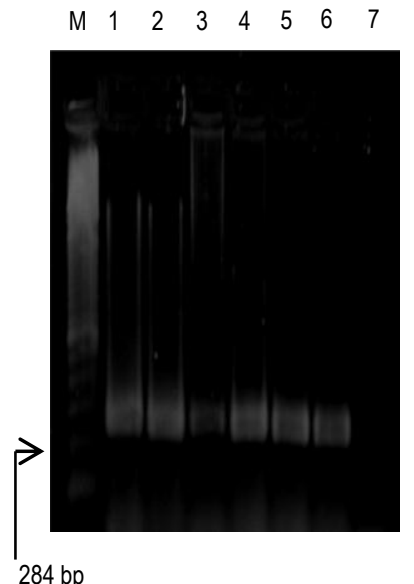

(a)
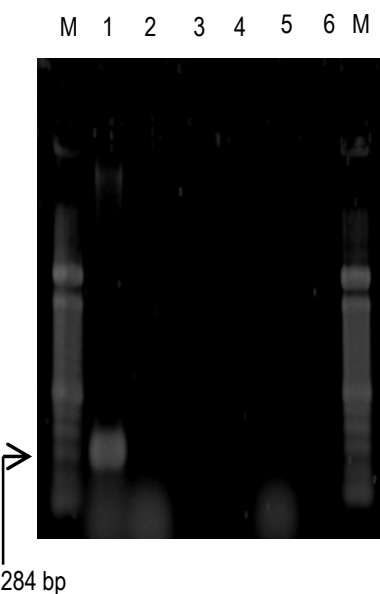

$284 \mathrm{bp}$

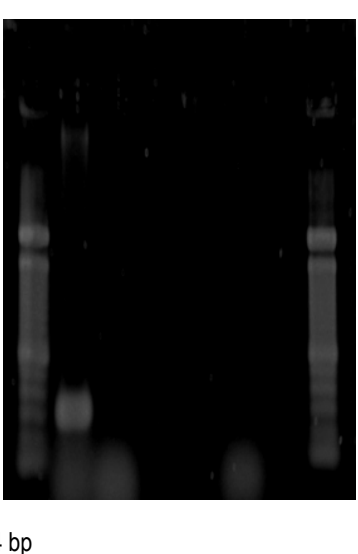

(b)
Figure 3. PCR specificity was evaluated by 5 different isolates of Salmonella serovar cross-tested with 5 non-Salmonella isolates a) lanes 1-6: S. Enteritidis, S. Hadar, S. Heidelberg, S. Kentucky, S. Paratyphi, and S. Typhimurium; lane 7: $S$. aureus as a negative control; lane M: 100 bp ladder DNA marker, b) lane 1: $S$. Typhimurium as a positive control; lanes 2-6 respectively: $E$. coli, $L$. monocytogenes, $P$. mirabilis, S. aureus and V. parahaemolyticus and lane M: DNA marker $100 \mathrm{bp}$ ladder

Results of the specificity test showed that the PCR protocol could be used for detecting of $284 \mathrm{bp}$ single band at overall 6 Salmonella isolates (Figure $3(\mathrm{a})$ ). The protocol did not detect any signal for 5 non-Salmonella isolates (Figure 3 (b)). InvA gene is a virulence gene in Salmonella that is important for invasion into the epithel cell of host. Invasion of intestinal epithelial cells is an important step in the pathogenicity of Salmonella infection. Karunasagar et al. (2012) suggested 17 areas of Salmonella Pathogenicity Island (PAI) and invA gene belong to the SPI 1, which is responsible for the invasion and infection by Salmonella (Knodler and Steele-Mortimer, 2005). Those studies indicated that the invA gene was specific for Salmonella as reported by Shanmugasamy et al. (2011).

\section{Application of the PCR based on invA gene for detection Salmonella from fresh markets shrimp}

Detection of Salmonella by conventional method consist of pre and selective enrichment which takes 48 hours shows that 3 out of 16 shrimp samples were positive $(18.75 \%)$ for Salmonella, with satisfactory final identification (80.9\%). However, the PCR which takes 2 hours showed that all samples were positive for Salmonella (Figure 4). The PCR method showed can more sensitive and faster than the conventional one. These results were similar to previous studies in shrimp, poultry, animal and clinical samples suggesting that PCR after enrichment detected more Salmonella as compared to the conventional method (Eyigor and Carli, 2003; Maciorowski et al. 2005; Upadhyay et al. 2010; Germini et al. 2011). The use of growth in selective medium for DNA extraction was expected to increase the number of presumptive Salmonella. Soumet et al.
(1999) reported that using poultry directly for DNA extractionwas not sufficient due to the high amounts of inhibitor, interference and growth inhibition by other competing bacteria. The inability of the conventional method to detect Salmonella in shrimp samples may be due to the viable but non culturable state of the pathogen (Guo et al. 2000).

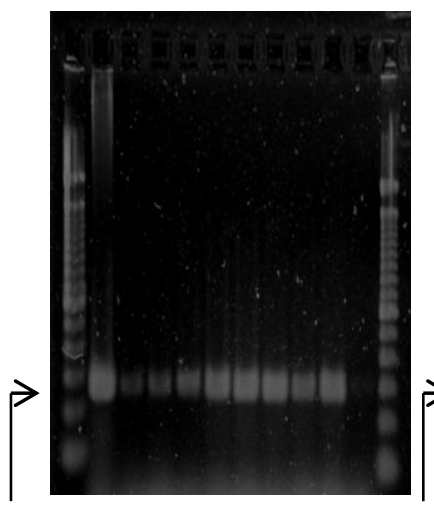

284 bp
M 123345567780910 M
M $1223 \begin{array}{lllllll}5 & 6 & 7 & 8 & 9 & 10 & M\end{array}$

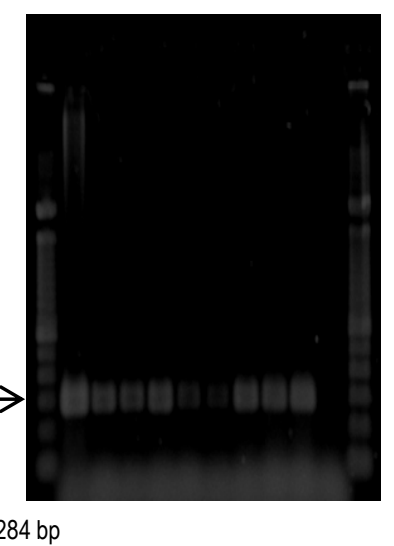

(b)
Figure 4. DNA visualization of invA gene Salmonella amplification products on a $1.5 \%$ agarose gel (TBE). PCR to detect Salmonella invA gene (a). Lane 1: $S$. Typhimurium DNA as positive control, lane 2-9: shrimp samples 1-8, respectively, lane 10: $S$. aureus DNA as a negative control (b) Lane 1: $S$. Typhimurium DNA as positive control, lane 2-9: shrimp samples 9-16, respectively, lane 10: S. aureus DNA as a negative control, lane M: DNA marker 100 bp ladder

\section{CONCLUSIONS}

Detection of Salmonella spp. based on invA gene could be performed with the following PCR protocol: pre denaturation $\left(95^{\circ} \mathrm{C}\right.$ for 1 minutes), denaturation $\left(95^{\circ} \mathrm{C}\right.$ for 30 seconds), annealing $\left(64^{\circ} \mathrm{C}\right.$ for 30 seconds), elongation $\left(72^{\circ} \mathrm{C}\right.$ for 30 seconds), and final extension $\left(72^{\circ} \mathrm{C}\right.$ for 4 minutes), with 35 cycles. Primer pairs F-139 and R-141 could amplified Salmonella invA gene specifically and had a high sensitivity with detection limit of $27.81 \mu \mathrm{g} / \mathrm{mL}$. Application of PCR assay in this research gave better detection of Salmonella spp. in shrimp than that of conventional method. Time required for PCR assay is faster than the conventional one, i.e. 2 hours for the PCR and 48 hours for enrichment.

\section{ACKNOWLEDGEMENTS}

This research was supported by Center for Research and Development and Product Processing and Marine Biotechnology Fisheries (CRDPPMBF) (2013), the Ministry of Marine Affairs and Fisheries, Slipi, Central Jakarta. 


\section{REFERENCES}

Devananda D. 2011. Study of Outer Membrane Proteins (OMPs) of Salmonella spp. and Development of OMP and Virulence Based Rapid Diagnostics for Food and Clinical Sample. [Dissertation]. Manipal University. Mangalore.

Dewanti-Hariyadi R, Suliantari, L Nuraida, S Fardiaz. 2005. Determination of Contamination Profiles of Human Bacterial Pathogens in Shrimp Obtained from Java, Indonesia. Proceedings of a final Research Coordination Meeting held in Mexico City, Mexico, 22-26 July. International Atomic Energy Agency.p 63.

Eyigor A, Carli KT. 2003. Rapid detection of Salmonella from poultry by real-time polymerase chain reaction with fluorescent hybridization probes. Avian Dis 47: 380-386.

Ellingson JLE, Anderson JL, Carlson SA, Sharma VK.2004. Twelve hour real-time PCR technique for the sensitive and specific detection of Salmonella in raw and ready to-eat meat products. Mol Cell Probe 18: 51-57.

Germini A, Masola, Paola C, Rosangela M. 2011. Simultaneous detection of Escherichia coli 0175:H7, Salmonella spp., and Listeria monocytogenes by multiplex PCR. Food Control 20: 733-738. DOI: 10.1016/j.foodcont.2008.09.010.

Guo X, Chen J, Beuchat LR, Brackett RE. 2000. PCR detection of Salmonella enterica serotype Montevideo in and on tomatoes using primers derived from hilA. Appl Environ Microbiol 66: 5248-5252.

Hyeon JY, Hwang IG, Kwak HS, Park C, Choi IS, Seo KH. 2010. Evaluation of PCR inhibitory effect of enrichment broths and comparison of DNA extraction methods for detection of Salmonella Enteritidis using real-time PCR assay. J Vet Sci 11: 143-149.

Karunasagar I, Bhowmick PP, Deekshit VK. 2012. Molecular aspects of pathogenesis and drug resistance in Salmonella species. In: Faruque, S.M. (Ed.), Foodborne and Waterborne Bacterial Pathogens. Caister Academic Press, Norfolk, UK: 121-152.

Knodler LA, Steele-Mortimer O. 2005. The Salmonella effector PipB2 affects late endosome/lysosome distribution to mediate Sif extension. Mol Biol Cell 16: 4108-4123.

Malorny B, Cornelia B, Reiner H. 2003. Evaluation of Salmonella spp.: Specific Primer-sets for the Validation within the Food PCR Project. Federal Institute for Health Protection of Consumers and Veterinary Medicine, National Reference Laboratory for Salmonella.

Maciorowski KG, Pillai SD, Jones FT, Ricke SC. 2005. Polymerase chain reaction detection of foodborne Salmonella spp in animal feeds. Crit Rev Microbiol 31: 4553.

Ministry of Marine Affairs and Fisheries. 2010. Statistic of Fishery Export 2011. Central Bureau of Statistics and Information.
Ministry of Marine Affairs and Fisheries. 2012. Statistic of Fishery Export 2011. Central Bureau of Statistics and Information.

Norhana MN, Poole SE, Deeth HC, Dykes GA. 2010. Prevalence, persistence and control of Salmonella and Listeria in shrimp and shrimp products: A review. Food Control 21: 343-361. DOI: 10.1016/j.foodcont.2009.06.020.

Rahn K, De Grandis SA, Clarke RC, McEwen SA, Galan JE, Ginocch OC, Curtissii R, Gyles CL. 1992. Amplification of inva gene sequence of Salmonella Typhimurium by polymerase chain reaction as a specific method of detection of Salmonella. Mol Cell Probe 6: 271-279. DOI: 10.1016/0890-8508(92)90002-F.

Rusyanto W. 2005. Prevalensi Serovar dan Galur Resisten Antibiotik Salmonella pada Rantai Produksi Udang Tambak [Tesis]. Bogor: Sekolah Pascasarjana, Institut Pertanian Bogor.

Sambrook J, Russel DW. 2001. Molecular Cloning: A Laboratory Manual $3^{\text {rd }}$ ed. Laboratory Press., Cold Spring Harbor. New York.

Shanmugasamy M, Thenmozhi V, Johnson R. 2011. InvA gene specific PCR for detection of Salmonella from broilers. Vet World 4: 562-564. DOI: 10.5455/vetworld.2011.562-564.

Soumet C, Ermel G, Rose V, Rose N, Drouin P, Salvat G, Collin P. 1999. Identification by a multiplex PCR-based assay of Salmonella Typhimurium and Salmonella Enteritidis strains from environmental swabs poultry houses. Lett Appl Microbiol 29: 1-6.

Trafny EA, Kozłowska K, Szpakowska M. 2006. A novel multiplex PCR assay for the detection of Salmonella enterica serovar Enteritidis in human faeces. Lett Appl Microbiol 43: 673-679.

Upadhyay BP, Utrarachkij F, Thongshoob J, Mahakunkijcharoen Y, Wongchinda N, Suthienkul O, Khusmith S. 2010. Detection of Salmonella invA gene in shrimp enrichment culture by polymerase chain reaction. Southeast Asian J Trop Med Pub Health 41:426-435.

Wilkerson RC, TJ Parson, DG Albright, TA Klein, MJ Braun. 1993. Random amplified polymorphic DNA (RAPD) markers readily distinguish cryptic mosquito species (Diptera: Culicidae: Anopheles). Insect Mol Biol 1: 205-211.

Yuwono T. 2006. Teori dan Aplikasi Polymerase Chain Reaction: Panduan Eksperimen PCR untuk Memecahkan Masalah Biologi Terkini. Penerbit ANDI Yogyakarta.

Zou W, Sufian FA, William SB, Tao H, James CF, Jing HSL, Foley, Joshua X, Hong F, Carl CE, Rajesh N. 2011. Microarray analysis of virulence gene profiles in Salmonella serovars from food/food animal environment. J Infect Dev Ctries 5: 094-105. 